\title{
MUSIK ROCK ALTERNATIF DALAM KALANGAN REMAJA: ISU SUB-BUDAYA REMAJA DAN PEMBANGUNAN INSAN DALAM ERA GLOBALISASI
}

\begin{abstract}
Rokiah Ismail'
Received Article: 12 Mei 2017

Accepted Article: 15 Juni 2017

Abstract

The debate on the involvement of youth in music is not a new topic in the discourses on youth and life styles. The article discusses a research work on a group of Malay urban youth in Malaysia who were involved in underground rock music and the activities associated with it. The qualitative research based especially on a collection of primary data analyzes the elements of the underground rock music and the dynamics of its particular subculture. It touches both the ideological and behavioral aspects related to the youth's involvement in underground rock music. The findings show that a group of Malay urban youth favors this type of music not only as a source of entertainment, but also underground rock music provides them with a channel to express their specific feelings, sentiments, and opinions associated with their specific life experiences, both as individuals and as a group within the society. Their involvement is very much related to factors such as the particular characteristic features of the music and the social elements or issues touched upon such as subjects on social consciousness, generational identity, individual's creativity, social status, choice and freedom. For many youth, these elements have significant meanings for their daily living experiences and lifestyles and they provide them with a strategy needed to position themselves in a certain niche for survival as a group in the changing society like Malaysia.
\end{abstract}

Key Words: Underground rock music, Youth subculture, Youth life styles, Generational identity, social resistance.

\section{A. PENGENALAN}

$\mathrm{P}$ embahasan berhubung keterlibatan remaja dalam musik bukan merupa kan satu perkara baru dalam wacana mengenai golongan remaja dan gaya hidup. Di Malaysia hal tersebut mula menjadi suatu isu sosial apabila dampak keterlibatan remaja dalam musik pop pada satu ketika dahulu, iaitu sekitar tahun 1960-an telah dikaitkan terutamanya dengan kewujudan satu sub-budaya remaja yang dianggap bukan konvensional. Namun peralihan masa dan perubahan zaman tidak melenyapkan sama sekali pengaruh musik terhadap golongan remaja dan minat mereka terhadap musik moden sehinggalah ke hari ini.
Tambahan pula proses modenisasi, antara lain, telah banyak membawa pelbagai perubahan kepada dunia musik bagi golongan remaja di hampir seluruh dunia. Proses globalisasi selanjutnya turut memainkan peranan secara langsung dan tidak langsung dalam memperkukuhkan lagi penawaran dan perluasan pelbagai musik moden terkini bersama idea-idea khusus berhubung dengan amalan (kegiatan yang berkaitan) musik dalam kalangan golongan muda.

Di Malaysia, remaja bandar teru tamanya lebih mudah memperoleh banyak informasi berhubung musik moden terkini lewat misalnya media cetak, media elektronik dan komputer.

\footnotetext{
${ }^{1}$ Penulis adalah dosen Jurusan Antropologi dan Sosiologi Universiti Kebangsaan Malaysia, Bangi, Selangor, Malaysia.
} 
Selain itu munculnya semakin banyak pusat membeli belah (shopping malls), gedung musik, dan tempat hiburan telah menawarkan pelbagai pilihan dan pengalaman kepada remaja untuk ikut serta dalam arena musik seperti musik rock. Keadaan ini sekaligus menjadikan musik sebagai sebahagian daripada gaya hidup yang normal bagi golongan tersebut. Minat dan amalan musik rock ini didapati lebih menonjol dalam kehidupan harian golongan remaja, teruta manya bagi mereka yang tinggal di bandar-bandar besar di Malaysia seperti di Kuala Lumpur, Selangor, Pulau Pinang dan Johor Bahru. Remaja yang terlibat meminati musik rock dan mengikuti amalan khusus berhubung musik tersebut bukan sahaja terdiri daripada remaja lelaki, bahkan juga remaja perempuan.

\section{Permasalahan Kajian}

$\mathrm{B}$ anyak kajian mengenai musik rock umumnya membahas mengenai bentuk, motif dan derajat keterlibatan golongan muda dalam musik berkenaan, isu-isu utama yang dikaitkan dengan musik rock, dan budaya yang terhasil dari amalan atau tingkah laku pengikut musik tersebut (seperti Frith 1978, Berger 1990, Brake 1980, Brake 1985, Chamber 1985, Garratt 2004, Gelder \& Thornton 1997, Goheen 1998, Ng Chong Meng 1994, Goh Chee Wee 1998, Skelton \& Valentine 1998, Roe 1999, Ababil 2006, Amir 2006 dan Fadly Fahmi 2008). Antara subjek yang sering dibahas termasuk jenis musik yang diminati sesuatu golongan remaja, hubungan musik dengan pembentukan identiti golongan remaja, musik dan kaitannya dengan budaya remaja serta permasalahan yang dihadapi remaja, peranan musik rock sebagai pembentuk arti atau makna dalam pengalaman hidup remaja, dan perluahan beberapa arti tertentu yang terkait dengan pelbagai tantangan harian yang dihadapi golongan remaja sebagai satu kelompok sosial dalam masyarakat.

Sehubungan itu, maka makalah ini cuba memperihal dan menghuraikan beberapa elemen utama dan kedinamikan satu sub-budaya musik rock alternatif, iaitu musik rock bawah tanah (underground rock music), dalam kalangan remaja Melayu bandar dalam konteks pelbagai proses transformasi sosial yang berlaku dan dampaknya terhadap kehidupan remaja. Musik rock bawah tanah dikategorikan sebagai musik alternatif, iaitu suatu musik pilihan segolongan pengikut dan peminat musik yang pada sebahagian besar dianggap berbeda daripada musik arus perdana yang dianggap sebagai satu gugusan musik yang lebih disenangi dan diterima masyarakat umum. Dalam makalah ini, yang dikategorikan sebagai musik alternatif adalah sejenis musik yang digelar musik rock bawah tanah yang dicirikan oleh pelbagai genre musiknya yang tersendiri.

Dalam arena musik, secara universal umumnya boleh berlaku satu keadaan apabila sesetengah musik rock arus perdana (seperti musik pop rock) sebe narnya lewat masa dan zaman 'diangkat statusnya' daripda musik rock bawah tanah. Misalnya sesetengah genre musik rock yang sebelumnya tergolong ke dalam musik rock bawah tanah (seperti musik rap, punk dan rock alternatif), setelah beberapa tahun berlalu ianya tergolong pula dalam kategori musik yang 'statusnya' sebaris dengan musik arus perdana yang lain. Keadaan ini boleh berlaku dalam dunia musik di negara Barat dan juga Timur.

\section{Tujuan dan Skop Kajian}

K ajian ini adalah satu hasil kerja yang lahirnya daripada satu kajian yang lebih besar lagi iaitu mengenai musik rock, modenisasi dan globalisasi. Ternyata terdapat beberapa perbedaan misalnya dari segi ciri-ciri musik, mesej dan 'daya tarikan (attractiveness)' antara musik rock aliran perdana dengan musik rock bawah tanah. Kajian yang bersifat kualitatif ini melihat bahawa musik rock bawah tanah di Malaysia lebih cenderung menghasilkan satu sub-budayanya yang tersendiri berbanding musik rock arus perdana. Lalu hal-hal tersebut yang amat menarik diperdalam dalam kajian untuk menge valuasi kekhususan musik rock bawah tanah. Kajian sosiologikal yang menggunakan data primer dan sekunder ini 
cuba memahami mesej yang ingin disampaikan atau tersirat dalam musik dan amalan musik rock bawah tanah. Kajian ini memanfaatkan interpretasi khusus berhubung musik dan amalan peminat serta penggiat musik rock bawah tanah dengan menggunakan perspektif pelaku. Pola amalan musik rock bawah tanah dilihat dari sudut hubungannya dengan gaya hidup remaja yang terlibat.

Sehubungan dengan peripentingnya musik sebagai satu komponen dalam gaya hidup remaja, maka kajian ini cuba meninjau beberapa pandang dunia (world views) remaja yang sering dikaitkan dengan fenomena amalan musik rock bawah tanah. Antara lain elemen-elemen yang sering ditampilkan atau tersirat dalam musik terse but adalah mengenai keadilan, autonomi, semangat untuk berdikari, kreativitas, pemerkasaan, dan pluralisme budaya yang wujud dalam masyarakat moden. Elemenelemen tersebut dianggap mempunyai arti dan dampak tertentu pada seseorang remaja, baik secara peribadi mahupun sosial sejajar dengan elemen-elemen seperti status, identiti, keseronokan dan kebebasan yang dianggap mencirikan sifat golongan remaja umumnya. Kajian ini cuba memperlihatkan kedua-dua aspek ideolo gikal dan yang berkaitan dengan tingkah laku (behavioral) yang terdapat dalam amalan musik rock bawah tanah dalam kalangan remaja yang terlibat.

\section{Metod dan Sampel Kajian}

$\mathrm{K}$ ajian ini dilakukan di beberapa buah kawasan bandar Kuala Lumpur dan daerah di sekitarnya. Golongan remaja yang terlibat adalah sebanyak 40 orang dan mereka berumur antara 15 hingga 25 tahun. Metod persampelan bertujuan telah digunakan dalam usaha menggumpul data primer. Responden kajian dikenal pasti apabila mereka didapati mempunyai minat terhadap musik rock kontemporari (pop), dan pada masa sama mempunyai minat yang tinggi khususnya dalam musik rock bawah tanah. Beberapa ciri khusus responden yang bersifat luaran juga diteliti untuk mempastikan kesesuaian diri mereka sebagai sampel kajian. Pemilihan sampel dilakukan secara snow- ball dan mereka telah ditemubual secara mendalam. Kajian awal dimulakan pada tahun 2004 dan penggumpulan data kualitatif diperluaskan lagi pada tahun 2005. Kajian kualitatif ini yang lebih menekankan aspek proses yang menimbulkan dan selanjutnya mengembang kan minat terhadap musik rock bawah tanah telah mengambilkira pelbagai interpretasi atau tafsiran peribadi remaja yang bersifat khusus berhubung tingkah laku mereka serta nilai-nilai di bawah permukaan tingkah laku (subterannean values). Nilai-nilai ini lazimnya mendukung pelbagai kecenderu ngan remaja untuk bergiat dalam pelbagai aktivitas yang terkait dengan musik rock bawah tanah.

\section{Kerangka Konseptual}

$T$ ingkah laku remaja yang terlibat dengan musik rock bawah tanah diandaikan mempunyai hubungan secara langsung dan tidak langsung dengan suatu budaya khusus yang dianuti bersama teman-teman. Budaya remaja itu pula mempunyai kaitan yang rapat dengan gaya hidup mereka.

Gaya hidup merujuk kepada pola khusus aktivitas-aktivitas harian yang mencirikan seseorang individu. Gaya hidup seseorang remaja dianggap unik, iaitu ianya boleh diartikan sebagai tidak sama dengan orang lain; tetapi, pada masa sama, gaya hidup itu diorientasikan kepada yang bersifat sepunya (common) dan yang sosial. Dengan kata lain, seseorang itu memilih gaya hidup dalam hubungannya dengan orang lain yang signifikan (Fornas and Bolin 1995). Lewat cara tersebut, beberapa orang individu dalam mana-mana masyarakat akan memilih gaya hidup yang memper lihatkan beberapa persamaan sepunya dan juga yang membedakan diri mereka dengan individu-individu lain. Penentu kepada pemilihan gaya hidup itu pula boleh dikaitkan dengan berbagai-bagai faktor yang boleh dikategorikan secara kasar kepada faktor struktural seperti status dan kelas sosial dan faktor bukan-struktural seperti citarasa dan minat (Weber 1966; Veblen 1966; Bourdieu 1984; Reimer 1989). Konsep sub-budaya dapat dibedakan daripada konsep gaya hidup terutama dari segi derajat intensitas tindakan menga 
malkan sesuatu aktivitas, impaknya dan persepsi masyarakat terhadap aktivitas berkenaan. Sub-budaya remaja mengan dungi satu set nilai dan emosi, kepercayaan, simbol, perlakuan, dan aktivitas yang dikongsi oleh sekumpulan remaja tertentu. Dalam perbincangan mengenai sub-budaya musik rock bawah tanah, hubungan antara gaya hidup dan sub-budaya remaja atau budaya remaja itu didapati amat dekat. Ternyata analisis mengenai sub-budaya atau gaya hidup remaja pada sebahagian besarnya bertindan dan ianya didapati sangat kompleks.

Kajian ini umumnya membicarakan ciri-ciri khusus amalan remaja dalam musik rock bawah tanah dan kaitannya dengan sub-budaya remaja dan gaya hidup remaja Melayu bandar. Dalam konteks suatu ruang sosiopsikologikal bagi remaja bandar yang dipengaruhi pelbagai tuntutan ekonomi dan sosiobudaya yang sangat dinamik dan mencabar, maka pengalaman remaja rock bawah tanah dianggap mempunyai kesignifikanannya yang tertentu bagi diri peminat atau penggikutnya. Minat terhadap musik rock bawah tanah, amalan subbudayanya yang unik dan gaya hidup yang diekspresikan oleh remaja diandaikan mempunyai hubungan langsung dan tidak langsung dengan jenis-jenis pengalaman yang dilalui dalam kehidupan harian mereka sebagai satu kelompok sosial dalam masyarakat Malaysia kini.

Ideologi dan tindak laku remaja rock bawah tanah mengekspresikan terutamanya sifat-sifat bersatu, berdikari dan berada 'di bawah satu bendera'. Nilai-nilai tersebut dihayati dan dimobilisasikan dalam usaha mengekalkan diri mereka sebagai agen sosial dan menjadikan golongan musik rock bawah tanah sebagai satu unit sosial yang terpadu. Tingkah laku remaja musik rock bawah tanah mempunyai impak yang nyata dan tidak nyata terhadap pembangunan remaja dari berbagai-bagai segi termasuk psikologikal, sosial, mental, spiritual dan emosi. Musik Rock Bawah Tanah Sebagai Musik
Alternatif Bagi Generasi Muda
$\mathrm{M}$ usik rock merupakan sejenis musik yang muncul pada pertengahan tahun 1950-an dan musik tersebut menjadi salah satu bentuk musik paling popular dalam kalangan remaja dan sesetengah orang dewasa di Amerika Syarikat dan Eropah Barat. Sejak tahun 1960-an terdapat pelbagai versi musik rock, misalnya classical rock, folk rock, country rock, jazz rock, pop rock, hard rock, acid rock, punk rock, alternative rock dan berbagai-bagai lagi. Definisi rock yang tepat sukar diberi, namun yang jelas dalam musik tersebut terdapat penekanan pada tempo (rentak) yang rancak dan penggunaan gitar listrik dalam semua jenis musiknya.

Musik bawah tanah merangkumi setiap genre musik yang umumnya tidak diterima masyarakat pada awalnya. Musik seperti jazz, rhythm \& blues (R\&B), country dan gospel yang mewarnai persada musik Amerika pada pertengahan tahun 1950-an merupakan beberapa genre musik yang diklasifikasikan sebagai musik bawah tanah. Ini karena penerimaan terhadap musik sedemikian agak terbatas memandangkan peminat-peminat musik ketika itu bersifat agak prejudis dan rasis terhadap para pemusik tertentu.

Tahun 1960-an merupakan tahun perintis bagi variasi musik yang kini dilabel sebagai musik bawah tanah. Kemunculan kumpulan The Beatles dan penyanyi Bob Dylon telah mengubah senario musik rock $n$ ' roll. Mereka telah memperkenalkan ideaidea dan bunyi (sound) baru rock n' roll dan senikata lagu yang lebih ekspresif. Keadaan ini berterusan terutamanya di Britain dan Amerika Syarikat sehingga pada akhir tahun 1960-an muncul pula musik rock yang dikenali sebagai punk scene dan metal scene yang menghasilkan lagu-lagu mengenai realiti kehidupan dan ekspresi atau pernyataan perasaan yang bersifat tidak hipokrit. Heavy metal scene pula turut menampilkan senikata lagu (lirik) yang berbau mistik, kehidupan selepas mati, dan penyakit mental. Antara genre musik yang menerima pengaruh metal scene ialah thrash metal, hardcore, heavy metal, rap dan grunge.

Di Malaysia, terdapat segelintir pemusik yang menginginkan kebebasan berkarya dan mereka cuba 'lari' dari 
kehendak pasaran dan tampil dengan idea tersendiri. Musik rock yang dihasilkan umumnya bersifat berat (heavy), dan senikata lagu pula tidak lagi menyentuh soal cinta tetapi lebih bersifat terbuka dan sebahagian besar musik tersebut menggunakan bahasa Inggeris. Kelahiran musik rock berbentuk baru ini pada sekitar tahun 1970-an dan 1980-an dikenali sebagai dunia musik bawah tanah. Bermula pada tahun 1988, keadaan menjadi hangat apabila semakin ramai remaja meminati musik seperti punk dan thrash metal. Musik tersebut mula dikategorikan secara lebih spesifik seperti death metal, industrial, grindcore dan sebagainya. Suasana dunia musik bawah tanah mula wujud apabila banyak band merakamkan demo-tape, membuat majalah (fanzine) dan menga dakan gig (konser kecil-kecilan). Mulai akhir tahun 1980-an musik thrash, death dan black metal dilabelkan sebagai musik bawah tanah. Pada tahun 1992, trend baru dalam musik bawah tanah di Malaysia menyak sikan kemunculan musik punk, alternative dan hardcore. Kemunculan musik punk, alternative dan hardcore seolah-olah menjadi trend baru dalam Underground Scene (UG Scene). Jenis musik tersebut seperti menempuh era baru selepas musik metal.

Kemeriahan dunia musik bawah tanah di Malaysia jelas dapat dilihat apabila gig atau koncer kecil mula giat diadakan. Selalunya gig dianjurkan sendiri oleh penggiat musik, band, editor majalah atau pemilik label musik. Gig sering bertempat di pub atau disko. Jika sesuatu gig akan diadakan, maka informasi mengenai konser itu akan disebarkan menggunakan flyers (kertas informasi) yang dihantar lewat surat kepada editor-editor fanzine atau temanteman mereka dalam dan luar negara. Kumpulan yang mengadakan konser kecil ini dikatakan tidak mementingkan keuntungan, tetapi yang paling diprioritas kan adalah semangat dan suasana happening (berseronok atau bersukaria bersama teman-teman) dan bersatu (united). Itulah prinsip dalam dunia musik bawah tanah. Bagi peminat dan penggiat genre musik tersebut, yang penting adalah amalan DIY (Do It Yourself), tanpa bergantung kepada sesiapa untuk mendapatkan bantuan kewangan dan sebagainya.

\section{CIRI-CIRI RESPONDEN DAN AKTIVITAS} MEREKA

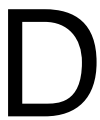
aripada 40 orang responden, sebanyak 27 orang (67.5 persen) adalah remaja lelaki sementara 13 orang lagi (32.5 persen) remaja perempuan. Distribusi umur mereka adalah seperti dalam Jadual 1.

Jadual 1: Frekuensi Responden Mengikut Umur

\begin{tabular}{ccc}
\hline Umur & Frekuensi & Persen \\
\hline 15 & 1 & 2.5 \\
16 & 5 & 12.5 \\
17 & 2 & 5.0 \\
18 & 6 & 15.0 \\
19 & 2 & 5.0 \\
20 & 4 & 10.0 \\
21 & 3 & 7.5 \\
22 & 8 & 20.0 \\
23 & 6 & 15.0 \\
24 & 2 & 2.5 \\
25 & 1 & 2.5 \\
\hline Jumlah & 40 & 100.0 \\
\hline
\end{tabular}

Jumlah responden yang bekerja dan masih belajar adalah hampir sama, iaitu masing-masing sebanyak 50.0 persen dan 45.5 persen, sementara 4.5 persen remaja tidak atau belum mempunyai sebarang pekerjaan. Bagi mereka yang bekerja, sebanyak 41.2 persen tamat Sijil Pendidikan Malaysia, 5.9 persen tamat Sijil Tinggi Pendidikan Malaysia, 17.6 persen mempu 
nyai kelulusan Diploma, sementara yang memiliki ljazah pula sebanyak 35.3 persen.

Terdapat banyak responden yang berasal daripada keluarga yang sekurangkurangnya berada dalam kategori kelas menengah bawah. Sebahagian besar remaja datang daripada berbagai-bagai kelas sosial. Walau bagaimanapun, kebanyakan responden yang ditemubual cenderung untuk tidak menyatakan kategori kelas sosial mereka. Ini karena mereka menganggap tidak terdapat 'perbedaan' kelas sosial dalam kelompok mereka (remaja yang meminati musik rock bawah tanah). Bagi mereka, diri mereka dan teman-teman adalah "sama sahaja" ("We are one and the same").

Golongan remaja yang terlibat dengan musik rock bawah tanah atau underground Scene (UG Scene) di Lembah Kelang (kawasan di daerah Kuala Lumpur dan sebahagian negeri Selangor) sering bertemu di tempat-tempat tertentu. Pada kebiasaannya mereka ditemui di tempattempat yang sering menjadi kunjungan umum para remaja. Tempat-tempat tersebut adalah sekitar kawasan Segitiga Emas Bandaraya Kuala Lumpur yang mempunyai beberapa kompleks perniagaan atau shopping malls seperti KL Plaza, Sogo, Campbell Complex, Pertama Complex, Lot 10 dan Kotaraya. Secara khusus, para remaja musik rock bawah tanah tertarik kepada tempat-tempat di mana kaset, demo-tape, majalah dan segala bentuk informasi mengenai dunia musik bawah tanah itu mudah diperolehi.

Jelas bahawa para remaja musik rock bawah tanah sering tertumpu di tempattempat di mana terdapat hiburan dan musik rock bawah tanah. Keadaan terdapatnya struktur fizikal urban di kawasan-kawasan bandar yang 'memudahkan' perkembangan suatu setting yang sesuai bagi musik rock jelas mempengaruhi minat remaja terhadap musik tersebut. Selanjutnya struktur fizikal di kawasan urban memungkinkan wujudnya suatu ruang awam (public space) bagi para remaja yang terlibat untuk memperluaskan budaya musik rock bawah tanah.

\section{KEISTIMEWAAN MUSIK ROCK BAWAH TANAH}

B anyak responden berpendapat baha wa meskipun secara kasar amalan meminati musik rock cenderung menunjukkan bahawa mereka 'terjurus' ke dalam satu budaya musik yang dianggap global atau sejagat, musik rock yang berkembang dalam kalangan mereka tidaklah sama secara total dengan yang terdapat di negara Barat. Secara luaran mungkin musik rock bawah tanah di Malaysia memperlihatkan sifat musik rock yang pada sebahagian besarnya lebih kurang sama seperti musik tersebut di Barat. Namun, pada masa yang sama sesetengah penggiat atau peminat musik rock masih peka terhadap nilai-nilai tempatan. Mereka cenderung mempercayai bahawa tidak semua nilai dalam budaya rock Barat itu perlu diserapkan ke dalam amalan musik rock tanah air oleh karena menurut mereka "... kita masih memerlukan pengadaptasian tertentu kepada budaya tempatan".

Para remaja dalam kajian ini menjelaskan bahawa mereka lebih berminat terhadap musik rock bawah tanah karena kebanyakan penggiat atau peminat dalam dunia musik bawah tanah seperti pemusik dan pemilik label syarikat rakaman bergerak secara bebas. Mereka juga mempunyai sikap dan ideologi tertentu dalam membentuk atau menghasilkan sesebuah musik. Pemusik dan pemilik label syarikat rakaman bukan sahaja menjadikan musik rock bawah tanah sebagai medium untuk mengekspresikan perasaan tertentu, tetapi mereka juga berusaha melahirkan satu sifat musik yang boleh membawa peminatnya kepada beberapa pegangan (prinsip) tertentu seperti bersikap anti-kapitalis, antiperang, anti-ras dan anti-autoriti. Lagu dan musik yang dihasilkan mempunyai kaitan rapat dengan sesuatu yang dilihat, didengar, dialami mereka dalam kehidupan harian atau elemen-elemen seperti pengaruh kapitalis, peperangan, rasisme dan seumpa manya tidak disenangi atau dikritik secara kolektif oleh golongan remaja itu sendiri.

Ciri-ciri musik rock seperti tersebut yang masih kekal dalam dunia musik bawah tanah menyebabkan remaja lebih meminati jenis musik itu. Ini karena sememangnya dunia musik bawah tanah merupakan suatu musik yang dihasilkan dengan cara yang 
lebih bebas berbanding musik di aliran perdana. Tambahan pula musik rock bawah tanah berjaya menyelitkan banyak sifat asas musik rock itu sendiri. Disamping itu, keadaan industri musik tempatan yang masih lebih dikuasai nilai-nilai komersil memperlihatkan bahawa musik rock yang dihasilkan lebih bermotifkan keuntungan tanpa menekankan pada sifat-sifat asas atau sebenar musik rock itu sendiri.

Rentak, senikata lagu, tema dan lagu merupakan ciri-ciri khusus dalam sesuatu jenis musik. Musik rock bawah tanah juga tidak terkecuali daripada mengandungi ciriciri tersebut. Umumnya musik rock alternatif ini memberi penekanan pada beberapa ciri utama seperti irama atau melodi, jenis musik, senikata lagu, tema, bahasa, 'pegangan' ('prinsip') dan 'sikap' seseorang penggiat itu sendiri.

Dari segi jenis musik, selalunya penggiat dan peminat musik rock bawah tanah menerima apa bentuk musik sekali pun asalkan musik tersebut tidak bersifat 'menentang' prinsip utama dunia musik bawah tanah itu sendiri, meskipun musik rock alternatif ini kurang dapat diterima sepenuhnya oleh masyarakat. Ini tidaklah berarti bahawa musik rock alternatif itu seharusnya berat dan bingit (amat keras), malah terdapat musik yang bersifat agak lebih ringkas serta 'ringan' (lighter) seperti musik alternative dan ska dalam musik rock bawah tanah.

Dari segi senikata lagu pula para responden mengakui bahawa senikata lagusenikata lagu yang dihasilkan dalam musik rock bawah tanah bersifat terbuka. Senikata lagu-senikata lagu tersebut menyentuh banyak aspek kehidupan. Terdapat musik yang bercirikan kritikan sosial, kemanu siaan, ketuhanan, kesengsaraan, politik, elemen mistik, alam sekitar dan sebagainya. Bagi golongan remaja dalam kajian ini tema-tema senikata lagu seperti tersebuat amat menarik.

Bahasa juga turut diambilkira sebagai salah satu ciri khusus lagu rock bawah tanah. Lebih banyak lagu dalam dunia musik bawah tanah berbahasa Inggeris, dan remaja juga turut memberi reaksi yang positif terhadap penghasilan lagu dalam bahasa Inggeris. Ciri-ciri khusus seperti musik, senikata lagu, tema dan bahasa memainkan peranan yang cukup penting dalam menjadikan musik rock bawah tanah itu diminati peminatnya. Kebanyakan peminat musik rock bawah tanah meminati jenis musik tersebut karena musik rock bawah tanah mempunyai ciri-ciri khusus yang menarik seperti dari segi senikata lagu, tema, rentak dan sikap pemusik itu sendiri. Bagi mereka, sememangnya ciri-ciri khusus itulah yang menunjukkan identiti musik rock yang asli atau sebenar berbanding ciri-ciri musik rock dalam aliran perdana.

\section{PANDANGAN PENGGIAT DAN PEMINAT MUSIK ROCK BAWAH TANAH BER HUBUNG PENGALAMAN HARIAN}

ecara umum pandang dunia merujuk
kepada cara seseorang individu
menginterpretasi (mentafsir) atau memberi arti kepada sesuatu hal atau objek dalam persekitaran sosialnya. Dalam kajian ini pandang dunia remaja terbatas kepada reaksi mereka terhadap orang dewasa, ibu bapa, pihak polis dan pihak-pihak berkuasa yang lain, iaitu golongan-golongan yang dianggap 'berwibawa' dalam masyarakat. Selain itu sikap remaja terhadap agama dan nilai-nilai tradisional juga turut diteliti. Tinjauan terhadap pandang dunia remaja dilakukan guna melihat kaitannya dengan dunia remaja secara umum dan kesejahteraan sosial golongan tersebut dalam kehidupan harian mereka.

Daripada kalangan 40 orang remaja, 32 orang (80.0 persen) memberi reaksi negatif terhadap pihak berkuasa dengan 'menuduh' bahawa 'pihak berkuasa selalu mencari masalah dengan remaja' atau 'mencari-cari hal' dan mereka (pihak berkuasa) juga sering menganggap golongan remaja sebagai 'musuh'. Umum nya yang dimaksudkan dengan pihak berkuasa adalah pihak polisi dan sebahagian kecilnya adalah juga sesete ngah pemimpin agama. Enam orang remaja (15.0 persen) berpendapat bahawa beberapa orang pegawai pihak berkuasa menjalankan tugas mereka dengan baik. Walau bagaimanapun secara umum mereka (pihak berkuasa) tetap memandang negatif remaja yang terlibat dengan amalan-amalan khusus berhubung dengan musik rock bawah tanah.

Selain pihak yang melaksanakan kuasa, remaja turut memberi reaksi negatif terhadap pihak pemerintah. Sebanyak 34 
orang responden (85.0 persen) mengakui bahawa pemerintah sebenarnya sering mempermasalahkan penglibatan remaja dalam musik rock bawah tanah sedangkan mereka "umumnya tidaklah terlibat dalam pelbagai gejala sosial yang serius seperti membuang waktu tanpa manfaat ('lepak'), seks bebas, kes juvana atau kes jenayah". Namun begitu, fenomena-fenomena seperti tersebut lebih sering dikaitkan dengan musik rock dan penggiat atau peminatnya sehingga menyebabkan masyarakat umum "memandang serong terhadap diri mereka" atau "remaja rock sering menjadi sasaran atau tumpuan utama kritikan masyarakat umum".

Sebanyak 32 orang remaja $(80.0$ persen) mempunyai tanggapan negatif terhadap golongan dewasa. Mereka berpen dapat golongan dewasa sering memper katakan bahawa sikap serta pandangan remaja sebagai 'masih mentah' dan "sesetengah mereka (orang dewasa) memandang negatif jika seseorang remaja cuba mengeluarkan kata-kata atau mengekpresikan pandangan dan melakukan sesuatu aktivitas seperti terlibat dalam musik rock bawah tanah". Bagi responden, penglibatan mereka dalam aktivitas seperti itu adalah sebagai suatu hak mereka. Responden menganggap golongan remaja bukan hanya menjadi korban perubahan yang berlaku dan dampaknya terhadap sistem masyarakat, malah golongan tersebut juga sering menjadi sasaran atau tumpuan utama kritikan sesetengah golongan dewasa.

Sebanyak 24 orang remaja $(60.0$ persen) berpendapat bahawa hubungan mereka dengan ibu bapa masih akrab dan orang tua mereka masih memberi ruang kebebasan untuk mereka meminati sebarang jenis musik. Keadaan ini berbeda dengan 16 orang responden (40.0 persen) yang menyatakan bahawa ibu bapa mereka tidak memahami langsung "kehendak jiwa remaja" yang cenderung meminati musik keras seperti musik rock. Bagi mereka faktor jurang generasi (generation gap) telah mempengaruhi perbedaan pendapat antara golongan remaja dengan ibu bapa mereka.

Secara keseluruhan remaja mem punyai pandangan yang positif terhadap agama karena agama dianggap penting sebagai pedoman hidup. Bagi mereka nilainilai baik atau positif dalam kehidupan mempunyai kaitan yang kuat dengan ajaran agama. Suatu yang dipermasalahkan oleh remaja adalah keadaan sesetengah anggota masyarakat yang "memandang remaja musik rock bawah tanah hanya dari segi luaran (misalnya dari sudut pakaian dan karektor mereka), sedangkan sikap dan kebaikan seseorang tidak seharusnya dilihat secara begitu misalnya lewat pakaian, pertuturan, penampilan diri atau sesuatu tingkah laku tertentu sahaja". Imej peminat atau penggiat musik rock bawah tanah tidak seratus persen melambangkan bahawa diri mereka 'berbeda' (berlawanan secara total) daripada 'orang biasa'. Remaja rock bawah tanah menjelaskan bahawa bagi diri mereka, apa yang lebih penting untuk dievaluasi adalah keikhlasan atau kejujuran niat seseorang. Para responden mengkritik segelintir anggota masyarakat terutamanya golongan dewasa atau pemimpin masyarakat yang cenderung memandang remaja musik rock bawah tanah hanya dari sudut luaran, sedangkan mereka "patut berusaha menyelami hal-hal yang sebenar yang tersirat dalam jiwa remaja seperti mereka (peminat atau pengikut musik rock bawah tanah)".

Secara umum remaja dalam kajian ini memberi respons yang positif terhadap nilainilai tradisional. Mereka masih akur pada nilai-nilai masyarakat seperti berlaku sopan, hormat-menghormati, tolong-menolong dan saling prihatin dalam kalangan anggota masyarakat. Semua ini dianggap penting demi kesejahteraan masyarakat bersama. Walau bagaimanapun terdapat segelintir responden yang mempunyai pandangan yang agak berbelah-bagi terhadap nilai-nilai tradisional masyarakat yang dianggap sangat mengawal atau menggongkong seseorang misalnya menyekat kebebasan individu untuk bersuara, atau sesetengah anggota masyarakat cenderung mengkritik cara penampilan seseorang lewat pa kaiannya, jenis musik yang dianggap 'melanggar tradisi' masyarakat Timur umumnya dan masyarakat Melayu khusus nya. Menurut segelintir responden sesetengah amalan tradisional masih perlu diteruskan, tetapi terdapat 'sesetengah adat resam' yang dianggap tidak lagi sesuai dalam dunia moden kini, seperti amalan 
suka menolak pandangan golongan anak muda atau remaja, mudah memandang serong atau negatif terhadap orang lain tanpa periksa, kurang berlaku adil terhadap orang muda dan sebagainya.

Pandang dunia yang memaparkan keresahan atau kekecewaan golongan remaja terhadap sesetengah bentuk kontrol sosial dalam masyarakat, penekanan mereka pada elemen-elemen kemanusiaan seperti hak dan keadilan, dan pandangan mengenai peripentingnya remaja kini diberikan 'sedikit' pilihan banyak mencirikan keinginan dan harapan peminat dan penggiat musik rock bawah tanah. Namun begitu, umumnya corak penentangan yang diperlihatkan oleh remaja Melayu bandar dalam kajian ini 'kurang lantang' atau 'kurang keras dan terbuka', masih terbatas dan tidaklah terlalu radikal.

\section{MUSIK ROCK BAWAH TANAH DAN BEBERAPA ISU KHUSUS YANG TERKAIT DENGANNYA}

(a) Isu Sub-budaya, Kesadaran Sosial dan Identitas Sosial

$\mathrm{M}$ usik pilihan atau musik alternatif bagi remaja dalam kajian ini dicirikan oleh suatu tindak balas yang tersendiri terhadap beberapa hal atau isu yang tersulam lewat musik rock bawah tanah. Mereka menganggap karya pemusik dan penyanyi musik rock sebagai sebuah 'hasil seni' dan dengan itu juga kreativitas karya tersebut menjadi satu sumber kepuasan bagi mereka. Ciri-ciri yang terdapat pada 'komunitas' musik rock bawah tanah membolehkan mereka dianggap sebagai satu sub-budaya. Komunitas tersebut, antara lain, mempunyai ruang perwacanaan yang 'sesuai' bagi diri mereka sebagai satu kelompok sosial. Tindakan 'mementingkan' hasil kolektif yang dihayati bersama oleh komunitas musik rock bawah tanah, secara langsung dan tidak langsung, merupakan cara bagi para pelaku menunjukkan potensi atau bakat (talent) dan menandakan kehadiran diri mereka sebagai satu kelompok sosial dalam masyarakat.

Mesej yang disampaikan lewat musik rock tersebut dan amalan peminat dan penggiatnya dianggap sebagai refleksi kehidupan, terutamanya kehidupan terban dar. Musik rock bawah tanah menjadi popular karena musik tersebut berupaya memberi suatu nafas dan pemahaman mengenai pelbagai aspek kehidupan terbandar seperti wujudnya (meskipun tidak selalu) perasaan terpinggir, resah, gelisah, terancam oleh pelbagai bahaya, dan keadaan yang menstimulasi daya pertahanan diri dalam proses mengadap tasikan diri dengan pelbagai perubahan dan 'hal-hal yang relatif baru' dalam hidup. Justeru, musik rock bawah tanah sebagai musik rock alternatif bagi golongan remaja dan keterlibatan peminat dan penggiatnya merupakan manifestasi pelbagai perasaan yang dikongsi secara kolektif bersama anggota lain seperti terdapatnya bibit-bibit ketakpuasan, kekecewaan, dan kata-kata yang berfungsi mempedomani hidup dalam dunia moden sekarang lewat pelbagai senikata lagu dan mesej yang ada pada lagu-lagu musik rock bawah tanah. Keterlibatan mereka dalam arena musik tersebut membawa bersamanya pelbagai mesej penentangan sosial (social resistance).

Kesignifikanan dan 'kuasa' musik rock bawah tanah tampak menonjol dalam meningkatkan kesadaran audiens mengenai senario umum ketakpuasan sesetengah golongan dalam masyarakat mengenai beberapa isu semasa, misalnya isu ekonomi dan politik. Setiap arti atau makna yang tersurat dan tersirat dalam musik rock bawah tanah menghasilkan impak terhadap masyarakat umum dan khususnya audiens sasarannya (target audience), iaitu pengikut atau peminat musik rock bawah tanah. Mesej dan senikata dalam musik rock bawah tanah baik secara langsung mahupun tidak langsung, misalnya, telah menarik perhatian sesetengah golongan masyarakat terutamanya remaja kepada isu-isu semasa berkaitan dengan peperangan, keterpinggiran, diskriminasi dan pelang garan hak-hak manusia.

Banyak dalam kalangan remaja yang mempunyai pandangan bahawa diri mereka adalah bahagian yang tidak kurang signifikannya dalam masyarakat. Justeru hal-hal yang bersangkutan dengan minat mereka terhadap sesuatu jenis musik dan tingkah laku mereka yang terkait dengannya secara langsung dan tidak langsung melambangkan identitas sosial mereka 
sebagai satu kelompok sosial yang tertentu dan yang perlu ada tempatnya (posisinya) dalam masyarakat. Sifat-sifat remaja seperti aktif, kreatif, sukakan hiburan, memerlukan derajat kebebasan yang tertentu, mengin ginkan ruang sosial, emosional dan fizikal seperti halnya dengan golongan lain demi menggunakan waktu senggang bersamasama teman-teman sebaya (peer group) merupakan sebahagian daripada identitas generasi yang tidak terpisahkan dari diri mereka yang sebenar sebagai satu kumpulan. Golongan ini juga turut menginginkan yang status mereka dalam masyarakat setempat terakomodasi dalam arus pembangunan masyarakat dan tidak langsung terkategori sebagai golongan 'minoriti' yang teralienasi dalam kehidupan harian dan dalam usaha untuk bersamasama tinggal sebagai warga masyarakat setempat.

\section{(b) Musik Rock Bawah Tanah dan Isu Ruang}

lsing su ruang disabitkan dengan dua jenis ruang yang harus diambilkira, iaitu ruang awam atau public space (merangkum ruang sosial dan fizikal) dan ruang persendirian atau private space. Beberapa persoalan dapat ditimbulkan dalam membahas mengenai isu ruang. Pertama, sejauhmanakah seseorang mempunyai 'hak milik' ('ownership') terhadap ruang awam dan ruang persendirian?; kedua, apakah pula kualitas 'hak milik' yang dipunyainya dalam kedua-dua aspek tersebut?; ketiga, sejauhmanakah seseorang anggota masya rakat itu diberi peluang untuk mengambil bahagian dalam ruang awam?; dan keempat, dalam situasi yang bagaimanakah pula seseorang itu dianggap 'penceroboh' atau 'pemusnah' (an invader or someone that interfers with) ruang awam?

Menurut Goheen (1998: 479), anggota masyarakat membentuk ruang awam yang bermakna lewat ekspresi, cara berfikir atau tingkah laku atau penyataan tuntutan, dan mereka menggunakan ruang awam bagi memenuhi tujuan dan keperluan mereka. Dengan jalan inilah ruang awam menjadi satu sumber awam yang bermakna atau berarti bagi mereka.

Dari satu sudut, isu ruang khususnya ruang awam boleh dianalisis dari segi wujudnya hubungan kekuasaan yang menentukan sejauhmana ruang awam (sosial dan fizikal) itu dapat dimiliki oleh pihak-pihak yang tertentu. Dalam hal ini, golongan peminat musik rock bawah tanah dan aktivitas musik rock bawah tanah dilihat sebagai satu komponen sosial yang dianggap menantang sempadan konven sional ruang untuk memperolehi dan menggunakan ruang sosial (atau fizikal) tersebut. Ruang sosial bagi kegiatan musik rock alternatif bagi remaja ini lebih cenderung tidak atau kurang menerima legitimasi umum dan oleh itu sering pula dipermasalahkan.

\section{(c) Tingkah laku Remaja dan} Penyimpangan Sosial

S esetengah pandangan umum (misa Inya daripada golongan dewasa dan pihak yang berkuasa) menganggap aktivitas atau amalan muik rock bawah tanah sebagai satu simtom ketakaturan (a symptom of disorder) pada norma dan nilai masyarakat umum sedia ada. Mungkin dalam hal ini, tingkah laku yang terkait dengan musik rock bawah tanah dianggap sama sekali 'sukar dimengerti' tetapi pada masa yang sama ianya juga suatu tingkah laku yang sukar 'dipersetujui umum'. Walau bagaimanapun, amalan tersebut dari sema sa ke kesama sentiasa mempunyai pengikut atau peminatnya yang tersendiri, dan pada sebahagian besarnya amalan mereka itu tidak mudah untuk dikawal ketat atau dikawal rapi secara berterus-terusan.

Secara kasar masyarakat boleh dibagikan kepada 'kelompok orang dewasa' dan 'kelompok orang muda atau remaja' dan terdapat perbedaan tertentu antara kedua-dua kelompok ini. Memang benar terdapat kelompok-kelompok lain dalam masyarakat seperti 'kelompok anak-anak' dan 'kelompok orang tua'. Namun dalam hal membahas mengenai musik rock alternatif ini, yang lebih sering diketengahkan adalah 'krisis' antara 'kelompok orang dewasa' dengan 'kelompok orang muda atau remaja'. Dari segi penyertaan anggota dalam masyarakat secara umumnya 'kelompok orang dewasa' tampak mempunyai ruang sosial dan fizikal yang lebih besar berbanding 'kelompok generasi muda atau remaja'. Justeru 'kelompok 
orang muda atau remaja' lebih cenderung dilihat dan dipersepsikan sebagai golongan yang tidak mempunyai kuasa yang sama dengan 'kelompok orang dewasa' atau mereka dipinggirkan dan dengan itu kurang berkuasa (powerless). 'Kelompok remaja' juga dilihat sebagai anggota masyarakat yang kurang mempunyai pilihan oleh karena mereka terpaksa akur pada kehendak dan nilai-nilai dominan yang berlandaskan garis ukuran golongan dewasa (White 1990).

Dalam kajian White mengenai golongan remaja di Australia, beliau mendapati golongan tersebut menghadapi pelbagai tekanan dan masalah apabila berbagai-bagai kontrol sosial seperti yang terdapat dalam bentuk kebijaksanaan umum, pekerjaan, pendidikan, latihan dan kerja komunitas 'dikenakan' ke atas mereka. Pelbagai latihan dan program kontrol sosial tersebut (program normalisasi) bertujuan mendisiplinkan golongan muda dan berperan mengisi masa senggang mereka. Namun kontrol sosial sedemikian me letakkan tekanan ke atas golongan remaja dalam artikata agar mereka akur pada cara bertindak seperti yang dituntut (dan ditentukan) oleh golongan dewasa. Lama kelamaan golongan muda berasa diri mereka telah kehilangan ruang (sama ada yang bersifat material atau bukan material) untuk mengekspresikan diri mereka sebagai individu. Ruang yang dimaksudkan termasuklah juga ruang untuk perkem bangan potensi dan kreativitas serta upaya untuk berdikari dari segi ekonomi dan sosial.

Menurut kaca mata masyarakat dewasa, sub-budaya generasi muda bukan sahaja sukar difahami, malah sub-budaya tersebut dicirikan oleh tindak laku tidak berakhlak (corrupt behavior) dan devian (Garratt 2004: 148). Sub-budaya musik rock bawah tanah, misalnya, dianggap mengan dungi sikap serta tingkah laku yang bersifat tidak akur pada nilai serta norma masyarakat (iaitu ianya bersifat nonconformist). Justeru selanjutnya kewujudan sub-budaya yang kebanyakannya melibat kan orang muda dilihat atau diinterpretasikan sebagai permasalahan sosial yang mengancam tata susila masyarakat konvensional dan ianya harus dibendung. Sehubungan dengan ini, maka bagi sesetengah pihak isunya juga adalah golongan belia harus 'dipimpin' oleh masyarakat dewasa.

Jalan penyelesaian yang bersifat simplistik tanpa mengetahui akar-umbi sesuatu permasalahan sosial boleh menyebabkan golongan remaja mudah dipersalahkan atau mereka menjadi korban kritikan masyarakat umum secara sewenang-wenangnya. Dengan kata lain, jalan penyelesaian yang simplistik dan bersifat segera (instant) lebih-lebih lagi oleh karena ianya dipengaruhi tingkat panik sosial yang relatif tinggi bagi sesetengah pihak dalam masyarakat, mempunyai kecenderungan untuk menyelesaikan 'per masalahan golongan muda' tanpa mengambil kira konsekuensi sampingannya secara terperinci dan juga secara hitung panjang. Pendekatan penyelesaian yang mempunyai elemen-elemen punitif, memak sa (coerce) serta mengontrol secara ketat (rigid) umumnya berkemungkinan besar akan hanya menyebabkan golongan sasar (golongan remaja) bagi kontrol sosial seperti tersebut berasa tidak berpuas hati, teralienasi dan berkemungkinan mengem bangkan sikap 'berpura-pura asal selamat'. Mereka dikatakan terlibat membangun dan mengembangkan bentuk-bentuk penenta ngan sosial secara terselindung ataupun manifest.

\section{AMALAN MUSIK ROCK BAWAH TANAH, CABARAN TRANSFORMASI SOSIAL DAN PEMBANGUNAN INSAN (MANUSIA)}

$\mathrm{M}$ eskipun pada sebahagiannya subbudaya musik rock bawah tanah di Malaysia telah mengalami beberapa proses pengadaptasian kepada keadaan sosial tempatan, secara umum sub-budaya musik rock tempatan masih banyak mengekalkan sifat asal musik rock termasuklah ideologi umumnya. Misalnya, banyak remaja rock mungkin didapati kurang berpakaian secara 'ektrim' dan kurang mendendangkan musik yang memuatkan mesej anti-agama, anti-pihak berkuasa dan sebagainya secara lantang, tetapi pada asasnya mereka berpegang pada ideologi yang menekankan elemenelemen perlunya berdikari, bersatu dan 'berada di bawah satu bendera' demi kesepaduan kelompok. Secara langsung dan tidak langsung, ideologi tersebut mempunyai kaitan dengan pandang dunia 
remaja dan reaksi mereka terhadap nilainilai tradisional, autoriti dan pengalaman khusus kelompok remaja. Tindak laku 'riang dan ekspresif" yang ditunjukkan sekumpulan remaja misalnya dalam sebuah konser musik adalah satu tindak laku kolektif bagi melahirkan perasaan 'gembira, seronok, tahan lasak (rugged) dan seakanakan membantah batas-batas budaya dan autoriti golongan dewasa dan pihak yang berwibawa'. Lewat musik dan penghaya tannya mereka juga terlibat dalam mengaksikan semula dunia remaja dalam satu bentuk dan konteks yang dianggap 'tepat dan sesuai' dan memungkinkan mereka melakukannya secara berkumpu lan.

Sub-budaya musik rock bawah tanah merupakan satu saluran bagi remaja 'mempraktikkan ciri-ciri remaja semasa'. Musik tersebut menawarkan suatu ruang sosial dan politik bukan sahaja untuk mereka berhibur atau 'berkumpul bersamasama', tetapi juga ruang untuk mengekspresikan identitas generasi (Roe 1999) dan tuntutan golongan muda yang dianggap paling "o.k., sesuai, kreatif dan bersemangat independent". Malah, bagi banyak peminat dan penggiat musik rock bawah tanah 'menikmati' sesuatu jenis musik merupakan sebahagian besar daripada gaya hidup remaja yang boleh dikatakan wujud tidak kira zaman, yakni terdapat pada sepanjang zaman.

Pada sebahagian besar, proses penyesuaian kepada keadaan sosial tempatan tidak menghalang undergrounders daripada terus berpegang pada prinsipprinsip yang menekankan penentangan terhadap ketakadilan sosial, kebebasan, perlunya berdikari dan kekal bersatu. Malah prinsip-prinsip asas dan penentangan sosial secara langsung dan tidak langsung berperan memformulisasikan pandang dunia anak-anak muda tersebut dalam konteks hubungan mereka dengan linkungan sosial, baik secara peribadi mahupun sosial.

Banyak penggiat dan peminat musik rock bawah tanah tampak melahirkan bibitbibit reaksi yang skeptik dan antigonistik terhadap sesetengah pihak dalam masyarakat, memberi pandangan yang tertentu mengenai situasi politik secara umum, menentang nilai-nilai yang dianggap 'ortodoks'. Mereka juga bersikap membenci golongan kapitalis yang mengeksploitasi "sesetengah segmen masyarakat", dan kumpulan yang "mengaut keuntungan yang sangat lumayan" daripada artis-artis dan kumpulan-kumpulan musik. Jelas, pada sebahagian besar, remaja yang terlibat secara langsung dalam dunia musik bawah tanah menjadikan musik mereka bukan hanya sebagai sumber hiburan, malah musik tersebut merupakan satu saluran untuk mengungkapkan perasaan, menyatakan sentimen dan mengekspre sikan pendirian diri remaja secara individual dan kolektif.

Kehidupan golongan muda sentiasa terarah kepada memenuhi pelbagai tuntutan sosial semasa. Mereka berdepan dengan pelbagai 'harapan' dan keterbatasan. Pelbagai cabaran yang dihadapi golongan muda secara langsung dan tidak langsung memainkan peran mempola sikap dan tingkah laku mereka. Dalam hal ini, yang diamati adalah keadaan remaja yang telah diperkasakan dari beberapa aspek lewat misalnya pendidikan, kewangan, informasi dan pilihan peribadi, tetapi pada masa yang sama mereka tidak terlepas daripada tuntutan-tuntutan semasa arus kapitalisme, pemodenan, budaya kepenggunaan, dan nilai-nilai kelompok. Pelbagai harapan, tantangan, tekanan dan kekecewaan golongan muda kadang- kala menimbulkan suatu tindak balas atau ekspresi berhubung dengan ketaksetujuan masyarakat dewasa, lantaran sering mengevaluasi secara simplistik suatu sub-budaya remaja seperti sub-budaya musik alternatif yang cenderung dikaitkan dengan elemen ancaman sosial atau 'musuh' kepada ketertiban sosial dalam masyarakat.

\section{KESIMPULAN}

A rtikel ini menyajikan satu kajian yang menunjukkan segolongan remaja Melayu bandar sebagai agen sosial yang berdepan dengan satu situasi yang dari satu pihak menarik, namun di pihak lain pula mungkin bersifat menantang suasana budaya tempatan. Dalam kalangan remaja musik rock bawah tanah, terdapat satu sistem arti (makna) dan tindak laku yang dikaitkan dengan amalan musik tertentu yang amat mereka minati. Justeru yang 
sering juga berlaku adalah proses negosiasi antara golongan tersebut dengan lingkungan sosial dan politik mereka. Keadaan ini merupakan satu pengalaman khusus dalam proses kelangsungan golongan remaja dalam masyarakat Malaysia kini yang seperti masyarakat lain sedang mengalami pelbagai transformasi sosial yang kompleks, sering berubah-ubah atau bersifat dinamis.

$$
\text { Kajian ini memperlihatkan }
$$

keterlibatan remaja Melayu bandar dalam satu budaya yang dari segi sejarahnya lahir di Barat, dan dalam banyak hal sesetengah anggota masyarakat menilainya sebagai sesuatu yang asing bagi budaya tempatan, lantas amalannya dipersoalkan atau dipertikaikan oleh sesetengah pihak. Namun begitu, kehadiran musik rock bawah tanah dalam dunia sosial banyak remaja di Malaysia kini sukar diusir disebabkan pelbagai faktor perubahan sosial yang kompleks serta dinamik, dan pelbagai faktor sosiopsiko logikal yang terkait dengan fasa remaja dan pengalaman hidup golongan remaja itu sendiri umumnya.

Keterlibatan remaja dalam musik merupakan satu budaya konsumsi yang nyata, yang padanya terungkap pelbagai sebab atau rasionalisasi yang tertentu. Amalan tersebut dikaitkan dengan pelbagai faktor seperti ciri-ciri khusus sesuatu musik dan isu-isu tertentu misalnya identitas, status, pilihan dan kebebasan. Selain itu, golongan remaja sendiri sebenarnya terlibat melakukan aktivitas yang berbeda daripada yang terdapat dalam situasi-situasi yang mereka perlu berada misalnya apabila di sekolah, rumah atau tempat kerja. Situasisituasi seperti tersebut yang bersifat 'konvensional' dianggap lebih rutin berbanding aktivitas yang berkait dengan penggunaan masa senggang. Elemenelemen seperti kreativitas, kebebasan, autonomi, pilihan, kesepaduan kelompok, dan pemerkasaan kelompok secara langsung dan tidak langsung mendasari minat dan keterlibatan remaja dalam musik rock bawah tanah.

Bagi sesetengah remaja, mengako modasi pelbagai elemen dalam bidang gaya hidup juga dianggap satu strategi untuk memposisikan diri mereka ke dalam satu niche yang diperlukan untuk kelangsungan hidup. Disebabkan musik rock berkait rapat dengan pelbagai pengaruh global, dan pada masa yang sama sesetengah golongan remaja perlu bertindak balas terhadap pelbagai tuntutan budaya dan agama, maka amalan musik juga melibatkan satu cara bagi remaja mengenal identitas golongan mereka (remaja) yang berbeda daripada identitas sosial golongan dewasa. Hal ini merupakan sesuatu yang amat relevan untuk direnungkan bersama oleh pelbagai pihak dalam menjana dan mengevaluasi pembangunan insan (manusia) secara saksama, bersifat semasa, berdaya maju dan berdaya tahan. Langkah ini mempunyai potensi yang cukup bernilai agar kita dapat membina masa depan masyarakat yang lebih menjamin keterlibatan golongan remaja secara aktif dan positif sekalipun pelbagai tantangan perubahan itu tetap ada bahkan mungkin meningkat.

Musik rock bawah tanah dan budaya yang terkait dengannya melambangkan keterbatasan remaja untuk berpartisipasi secara fleksibel dan berarti dalam musik rock aliran perdana sebagai salah satu wadah penggunaan waktu senggang dan dalam menjalani kehidupan harian mereka. Selain itu apabila musik rock bawah itu dikaitkan dengan budaya remaja atau gaya hidup segolongan remaja tertentu, yang sering dipermasalahkan adalah tingkah laku mereka yang dianggap kurang positif. Dengan itu, tampil sesetengah agen kontrol sosial dengan 'aparatnya' yang tertentu memainkan peran mencorak atau menormalisasikan kehidupan remaja rock bawah tanah, khususnya dalam arena penggunaan waktu senggang.

Sekiranya pembangunan insan itu dianggap penting dan perlu menekankan komponen insan atau manusianya, maka beberapa manifestasi nilai dan pandang dunia golongan remaja lewat minat dan penglibatan mereka dalam musik rock bawah tanah sebagai musik alternatif mempunyai kerelevanannya yang tertentu dalam usaha membina dan selanjutnya memupuk kesejahteraan bagi golongan remaja. Dalam kajian ini remaja yang terlibat dalam musik rock bawah tanah dan 'laungan' musik mereka diandai 'mendendangkan' sentimen-sentimen kolek tif berhubung dengan pelbagai pengalaman khusus mereka dalam masyarakat. Nilainilai yang dikongsi dan budaya yang diamalkan remaja bandar ini mempunyai hubungan yang dekat dengan kesadaran 
mereka mengenai betapa pentingnya ukuran-ukuran lain selain ekonomi atau material dititikberatkan dalam mempastikan wujudnya keadilan dan kesejahteraan bagi generasi muda negara.

\section{DAFTAR KEPUSTAKAAN}

Ababil. 2006. Underground vs. Mainstream. Fahamkah anda? Rhythms of The Third World (ROTTW), 1 Februari, ms. 50.

Amir Husairi Sharif. 2006. Apa Ada Pada Lirik? Dewan Budaya, Mei, ms. 24-25.

Amir Husairi Sharif. 2006. Bahasa, Musik, dan Komunikasi. Dewan Bahasa, Ogos, ms. 5456.

Baird, N. Youth, Subculture and Style. Dalam http://chi.freeservice.com/ youthsubcultureandstylehtml\#top. 7/10/2010.

Berger, E. 1990. From Rock to Rock: The Music of the Darkness Exposed. USA: Hunting House Inc.

Bourdieu, P. 1984. Distinction: A Social Critique of the Judgement of Taste. London: Routledge and Kedan Paul.

Brake, M. 1980. The Sociology of Youth Culture and Youth Subcultures. London: Routledge.

Brake, M. 1985. Comparative Youth Culture: The Sociology of Youth Cultures and Youth Subcultures in America, Britain and Canada. London: Routledge and Kegan Paul.

Chamber, I. 1985. Urban Rhythm: Pop and Popular Culture. London: Mac Millan Publishers Limited.

Clarke, J., S. Hall, T. Jefferson and B. Roberts. 1976. Subcultures, cultures and class: A theoritical overview. DIm. Hall, S. and T. Jefferson (eds.). Resistance Thro' Rituals. London: Hutchinson.

During, S. (ed.). 1995. The Cultural Studies. London: Routledge.

Fadly Fahmi Mokhtar. 2008. Antara Irama Lagi dan Kebebasan Bermuzik. Konsert, Disember, ms. 31.

Fornas, J. and G. Bolin (ed.). 1995. Youth Culture in Late Modernity. London: Sage Publications.

Frith, S. 1978. The Sociology of Rock. London: Constable and Company Ltd.

Frith, S. (ed.). 1988. World Music, Politics and Social Change. Manchester: Manchester University Press.

Garratt, D. 2004. Youth cultures and sub-cultures. DIm. Roche, J. S., Tucker, r. T. \& Flynn, R.. Youth In Society. London: Sage.

Gelder, K. and S. Thornton . (eds.) 1997. The Subcultures Reader. London: Routledge.

Goh Chee Wee K.R. 1998. Musik rock dan sub-budaya remaja. Latihan IImiah. Jabatan Antropologi dan Sosiologi, Fakulti Sains Kemasyarakatan dan Kemanusiaan, Universiti Kebangsaan Malaysia.

Goheen, P. G. 1998. Public space and the geography of the modern city. Progress in Human Geography, 22 (4): 479-496.

Griswold, W. 1994. Cultures and Societies in a Changing World. London: Pine Forge Press.

Hendry, L.B. et al. 1993. Young People's Leisure and Lifestyles. London: Routledge.

Hurrelmann, K. and U. Engels (eds). 1989. The Social World of Adolescents. New York: de Gruyter.

Khairul Nizam Zainal Badri. 2004. Faktor-faktor Yang Mempengaruhi Perkembangan Muzik. Rhythms of The Third World (ROTTW), Mac, ms. 44.

Mahbub ul Haq. 1995. Reflections on Human Development. New York: Oxford University Press.

Ng Chong Meng Andy. 1994. Sub-budaya RAP di kalangan remaja bandar Kuala Lumpur. Latihan IImiah. Jabatan Antropologi dan Sosiologi, Fakulti Sains Kemasyarakatan dan Kemanusiaan, Universiti Kebangsaan Malaysia.

Raja Iskandar. 2005. Apa Itu Underground Di Sebalik Mainstream? Rhythms of The Third World (ROTTW), Jun, ms. 20-24. 
Reimer, B. 1989. Postmodern Structures of Feeling: Values and Lifestyles in the Postmodern Age. DIm. Gibbons, J. R. (ed.). Contemporary Political Culture: Politics in a Post-modern Age. London: Sage.

Rice, F.P. 1990. Adolescent: Development, Relationships and Culture. Massachusetts: Simon and Schuster Inc.

Roe, K. 1999. Music and Identity Among European Youth. Music as Communication. Soundscapes, vol. 2, July. www.icce.rug.nl/ soundscapes/.../MIE/Part2_ 8/10/ 2010.

Skelton, T. and G. Valentine (eds). 1998. Cool places, geographies of youth cultures. London: Routledge.

Slater, D. 1997. Consumer Culture and Modernity. Cambridge: Polity.

Veblen, T. 1966. The Theory of the Leisure Class. DIm. Bendix, R. and S.M. Lipset (eds.). Class, Status and Power. New York: The Free Press.

Weber, M. 1966. Class, status and party. DIm. Bendix R. and S. M. Lipset (eds.). Class, Status, and Power: Social Stratification in Comparative Perspective (2nd. Ed.). N.Y.: Free Press.

Weinstein, D. 1994. Rock: Youth and Its Music. DIm. Epstein, J. (Ed.). Adolescents and Their Music: If It's Too Loud You're Too Old. New York: Garland Publishing.

White, R. 1990. No Spaces of Their Own: Young People and Social Control in Australia. New York: Cambridge.

Wicke, P. 1990. Rock Music: Culture, Aesthetic and Sociology. Cambridge: Cambridge University Press.

Woo, R. 2004. Apathetic Youths or Pathetic Adults? Malaysiakini, 12 Mei. (atas talian) http://www.malaysiakini.com/news/2953 16 Oktober 2005. 